\title{
Major Salivary Gland Cancer pTO TNM Finding v6 and v7
}

National Cancer Institute

\section{Source}

National Cancer Institute. Major Salivary Gland Cancer pTO TNM Finding v6 and v7. NCI

Thesaurus. Code C65080.

Major salivary gland cancer with no evidence of a primary tumor. (from AJCC 6th and 7th Eds.) 